\title{
GENIUSS
}

OJS: http://genius.iain-jember.ac.id

\section{DESAIN PENDIDIKAN ANAK USIA DINI DALAM PERSPEKTIF AL-QUR'AN DAN HADITS}

\author{
Sulaiman \\ Universitas Jember \\ sulaiman_mk@ymail.com
}

\begin{abstract}
Education for children in early ages is often not well planned by many parents. This departs from an assumption that early childhood education is not an important thing. So that, the education provided for them is just including some physical functions. This assumption causes parents not to consciously carry out a good education, especially in a habituation model. Getting used to see the good things, hearing the good things and feeling the good things are important for the children's psychological maturity.
\end{abstract}

Keywords : early childhood education design, al-qur'an and hadith's perspective

\begin{abstract}
Abstrak
Pendidikan anak di masa usia dini sering tidak direncanakan dengan baik oleh banyak kalangan, terutama orang tua. Hal ini berangkat dari anggapan sebagian orang tua yang berasumsi bahwa pendidikan dini masih kurang penting. Sehingga pendidikan yang diberikan semata-mata optimimalisasi fungsi fisik semata. Asumsi yang demikian ini menyebabkan orang tua tidak dengan sadar melakukan pendidikan yang baik, terutama dengan pendidikan model pembiasaan. Membiasakan melihat yang baik, membiasakan mendengar yang baik dan membiasakan merasa yang baik, semua itu penting dilakukan untuk kematangan anak dari sisi psikis.
\end{abstract}

Kata kunci: desain pendidikan anak usia dini, perspektif al-qur'an dan hadits

\section{Pendahuluan}

Pendidikan merupakan segala pengalaman hidup yang dialami oleh seseorang dalam lingkungan hidupnya. Ia bisa berlangsung dalam durasi yang cukup lama, bentuk yang beragam, jenjang yang hirarkis. Anak merupakan sosok individu yang memiliki karakteristik unik, ragam potensi, dan kecenderungan yang bervariasi. Oleh sebab itulah maka 
pendidikan harus direncanakan dengan baik sehingga dapat menyalurkan potensi setiap anak dengan baik. Masa anak-anak merupakan masa emas yang seharusnya dimanfaatkan oleh setiap orang tua supaya dapat mendidik, menanamkan nilai-nilai yang baik terhadap anaknya. Masa anak-anak adalah masa yang bebas dari seluruh macam kecendrungan pribadi. Ia akan condong pada lingungan yang membersarkannya. Hal ini ditegaskan juga oleh al Ghazali dalam kitab Ihya' Ulumiddin bahwa anak merupakan amanat yang Allah titipkan di tangan kedua orang tunya. Hatinya yang bersih merupakan permata berharga, lugu dan bebas dari segala macam lukisan dan gambaran. Oleh sebab itu maka ukirlah hatinya dengan ukiran yang baik supaya ia kelak menjadi pribadi yang dapat meraih kebahagiaan dunia dan akhirat ${ }^{1}$

Atas dasar itulah maka kami tertarik untuk mengupas, mengurai dan sekaligus menganalisis bagaimana al Quran dan hadits dalam memberikan rambu-rambu, embrio konsep tentang cara-cara, kiat, prinsip dalam mendidik anak sejak dini. Desain yang kami tawarkan diharapkan dapat menjadi bahan, pengalaman bagi pihak terkait untuk dipraktikkan dalam melakukan pendidikan terhadap anaknya.

\section{Tinjauan Literatur}

Term-term Al-Qur'an mengenai perkembangan manusia sangat perlu untuk dianalisis secara tematik (maudhu'i). Dari hasil analisis terhadap sejumlah ayat Al-Qur'an dan keterangan hadits yang relevan ditemukan bahwa perkembangan anak merentang dari lahir hingga usia puberbas yang ditandai dengan ihtilam. Dalam tadisi hukum Islam disebut aqil baligh. Tujuh tahun pertama perkembangan anak itu disebut anak usia dini. Pada rentang perkembangan usia 0-7 tahun itu, anak ada pada fase ahliyatul wujub. Anak laksana raja yang berhak mendapatkan layanan pendidikan secara prima dan belum dibebani kewajiban hukum. Akhir capaian pendidikan anak usia dini adalah menjadi individu mandiri. Menjadi mumayyiz yang memiliki kompetensi dasar untuk menjalankan taklif Allah, berupa peribadatan dan ketentuan norma syariat; mampu menolong diri sendiri dan orang lain, berani mengambil keputusan dan sanggup memecahkan masalah secara bijaksana, serta bangga menghasilkan karya baru. Kompetensi ini ditanamkan kepada anak melalui proses tarbiyah yang menekankan pada tindakan rahmah membimbing anak menjadi berdaya dengan berbagai keterampilan hidup. Di sisi lain, proses pembudayaan nilai-nilai

1 Abu Hamid Muhammad bin Muhammad, Ihya' Ulumiddin, Jilid III, (Beirut: Darul Fikr, tt), hlm. 66 
dilakukan melalui proses ta'dib yang menekankan pada penanaman sikap disiplin dan budaya tertib.

\section{Metode}

Metode penelitian yang digunakan adalah metode kualitatif. Sedangkan jenis penelitian ini adalah penelitian kepustakaan (library research) yang dilakukan dengan cara mengumpulkan data dari berbagai sumber kepustakaan seperti Al-Qur'an dan Hadits, buku dan karya tulis ilmiah dengan data-data kepustakaan sebagai objek penelitian dengan pendektan analisis isi. Al-Qur'an dan Hadits sebagai sumber utama dikaji dengan pendekatan teori psikologi dan pendidikan.

Penelitian dengan metode kajian pustaka ini berusaha menjawab pertanyaan tentang pendidikan anak usia dini. Pada rentang usia berapakah seseorang disebut anak? Apa paradigma pendidikan yang relevan untuk anak? Dengan cara bagaimanakah proses mendidik anak usia dini yang tepat menurut Islam? dan bagaimana desain pendidikan anak usia dini dalam perspektif al-Qur'an?

\section{Hasil dan Diskusi}

Pendidikan Anak Usia dini merupakan lumrah didiskursus terkait dengan pendidikan anak usia dini ini menjadi penting dalam mendidik dan berikan asuhan yang lebih baik. Sebab nilai-nilai Islam yang diterapkan pada Anak Usia Dini kurang optimal sehingga penulis akan menguraikan bagaimana konsep pendidikan Anak Usia Dini dalam persfektif Islam baik dari kurikulum, materi pembelajaran, metode dan lingkungan yang mempengaruhi pendidikan Islam, $\mathrm{Hl}$ ini karena dalam kegiatan proses pembelajaran kurikulum sangat dibutuhkan.

Kurikulum merupakan pedoman untuk menyusun target dalam proses belajar mengajar. Namun memahami hakikat kurikulum sering terjadi perbedaan persepsi dan pemahaman. Sementara H. Dakir mengemukakan bahwa kurikulum itu merupakan program pendidikan bukan program pengajaran, yaitu program yang direncanakan diprogramkan dan dirancangkan yang berisi berbagai bahan ajar dan pengalaman belajar yang baik berasal dari waktu yang lalu, sekarang maupun yang akan datang. Ada berbagai bentuk kurikulum yang dikembangkan oleh para ahli dalam pendidikan anak usia dini. Ada yang disebut dengan Kurikulum terpisah-pisah, yakni kurikulum mempunyai mata pelajaran yang tersendiri satu dengan lainnya tidak ada kaitannya, karena masing-masing mata pelajaran mempunyai organisasi yang terintegrasikan. Ada pula kurikulum saling berkaitan, yakni antara masing-masing mata pelajaran ada keterkaitan, antara dua mata pelajaran masih ada kaitannya. 
Dengan demikian anak mendapat kesempatan untuk melihat keterkaitan antara mata pelajaran, sehingga anak masih dapat belajar mengintegrasikan walaupun hanya antara dua mata pelajaran. Kemudian ada pula yang dinamai dengan Kurikuluim Terintegrasikan, dalam kurikulum ini anak mendapat pengalaman luas, karena antara satu mata pelajaran dengan mata pelajaran lain saling berkaitan. Dalam kaitannya dengan materi pendidikan untuk anak usia dini, Ibnu Sina telah menyebutkan dalam bukunya yang berjudul As-Siyasah, ide-ide yang cemerlang dalam mendidik anak. Dia menasihati agar dalam mendidik anak dimulai dengan mengajarkannya al-Qur'an al-Karim yang merupakan persiapan fisik dan mental untuk belajar. Pada waktu itu juga anak-anak belajar mengenal huruf-huruf hijaiyah, cara membaca, menulis dan dasar-dasar agama. Setelah itu mereka belajar meriwayatkan sya'ir yang dimulai dari rojaz kemudian qashidah karena meriwayatkan dan menghafal rojaz lebih mudah sebab bait-baitnya lebih pendek dan wazn (timbangan)-nya lebih ringan. Sebaiknya dalam hal ini, guru memilih sya'ir tentang adab-adab yang terpuji, kemuliaan orangorang. ${ }^{2}$

\section{Pendidikan Anak Usia Dini dalam Al-Qur'an dan Hadits}

Hal pertama yang harus dilakukan dan diperhatikan dalam konsep pendidikan seorang anak adalah seruan Allah Swt untuk menjaga keluarga kita dari api neraka.

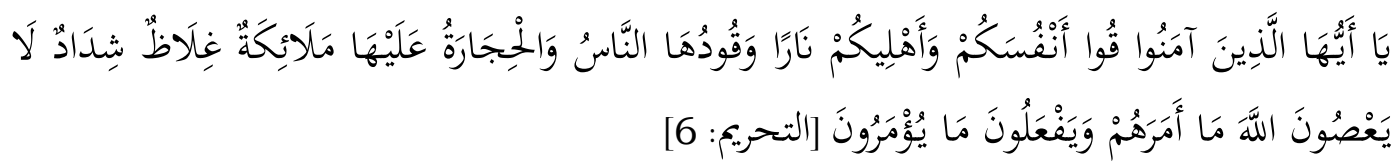

Hai orang-orang yang beriman, peliharalah dirimu dan keluargamu dari api neraka yang bahan bakarnya adalah manusia dan batu; penjaganya malaikat-malaikat yang kasar, keras, dan tidak mendurhakai Allah terhadap apa yang diperintahkan-Nya kepada mereka dan selalu mengerjakan apa yang diperintahkan. [QS. Al Tahrim. 06]

Mengenai makna "menjaga" Al-Mawardi memberikan tafsiran yang beragam, di antaranya adalah menjaga dengan cara memberikan nasehat. [1] berkaitan dengan ketaatan kepada Allah Swt, [2] mengajarkan tentang kewajiban dan budi pekerti dalam perkara dunia, [3] mengajarkan tentang kebaikan dan memerintahkan untuk melakukannya. Seruan Allah tersebut semata-mata berkaitan dengan keselamatan manusia di dunia dan akhirat. Sekaligus merupakan

2 Hafni.Ladjid, Pengembangan Kurikulum Menuju Kurikulum Berbasis Kompetensi. (Ciputat : Quantum Teaching, 2005), 1 7H Dakir, Perencanaan dan Perkembangan Kurikulum. (Jakarta: PT Rineka Cipta, 2010), 3 
kewajiban bagi setiap orang tua terhadap anaknya. Mengingat anak merupakan bagian dari keluarga yang tanggung jawabnya berada pada orang tuanya. ${ }^{3}$

Adapun penjelasan al-Qur'an yang berkaitan dengan konsep pendidikan anak usia dini secara khusus, maka melalui ayat di bawah ini Allah Swt menjelaskan tentang apa yang harus dilakukan oleh orang tua sebagai sebagai pendidikan pertama bagi anaknya.

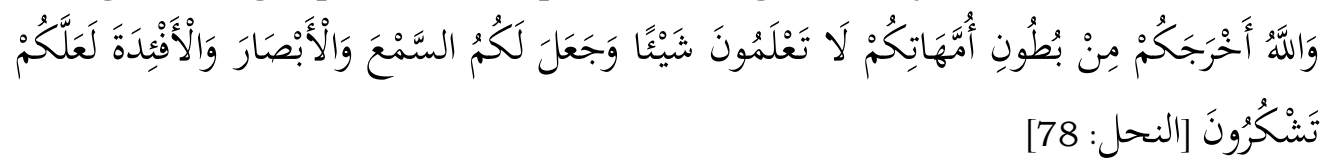

Dan Allah mengeluarkan kamu dari perut ibumu dalam keadaan tidak mengetahui sesuatupun, dan Dia memberi kamu pendengaran, penglihatan dan hati, agar kamu bersyukur. [QS. Al Nahl. 78]

Menurut Al Razi, melalui ayat Allah Swt hendak menjelaskan bahwa jiwa manusia pada awal penciptaannya tidak dibekali ilmu dan pengetahuan. Bahwasanya Allah Swt membekalinya dengan panca indra untuk digunakan sebagai alat, perantara memperoleh ilmu dan pengetahuan. Lebih lanjut lagi Ar-Razi mengurai pendapat mufassir tentang makna "as-sam'a", yang Allah ciptakan untuk mendengar titah Allah Swt, "al-abshar" yang Allah ciptakan untuk mengetahui secara mendalam tentang tanda-tanda kekuasaan Allah dan "al-af'idah" untuk memikirkan keagungan Allah. ${ }^{4}$

Melalui ayat ini dan berdasarkan tafsiran yang diberikan oleh ArRazi, dapat dipahami bahwa Allah memberikan bekal terhadap manusia dengan dua bentuk. Yaitu sarana indrawi dan sarana 'aqli. Dengan indrawi manusia dapat mengetahui obyek-obyek mahsusat (obyek indrawi) dengan 'Aqli manusia dapat mengetahui obyek-obyek ma'qulat (obyek nalar).

Kemudian yang berkaitan dengan dimensi ruhani seorang anak, penjelasan yang lebih fokus termaktub dalam hadits nabi.

$$
\text { السنن الكبرى للبيهي : :عن أبى هريرة قال قال رسول الله صلى الله علهيه وسلم كل مولود }
$$

Setiap anak dilahirkan dalam keadaan Fitrah, kemudian kedua orang tuanyalah yang menjadi pelantara ia menjadi Yahudi dan Nashrani. [HR. Abu Hurairah] ${ }^{5}$

${ }^{3}$ Al Mawardi, Al Nuktu wa al 'Uyun, Jilid IV (Maktabah syamilah), hlm.

${ }^{4}$ Fakhruddin Ar Razi, Mafati al Gaib, (Maktabah Syamilah), hlm. 275

5 Al Baihaqi, Sunan al Qubra, Jilid VI, (maktabah syamilah), hlm. 202 
Hadits ini mengandung banyak makna, terutama berkaitan dengan kata "Fitrah". Sebagian ahli hadits menafsirkan bahwa yang dimaksud dengan fitrah adalah agama Islam. Hanya sanya orang tuanyalah yang menyebabkan ia berpindah agama terhadap agama kedua orang tuanya. Sedangkan ahli hadits yang lain menafsiri bahwa setiap anak dibekali potensi yang dipersiapkan untuk dapat menerima agama yang benar. Sehingga seandainya ia dibiarkan dalam keadaan seperti semula maka ia akan tetap menjadi Fitrah. Karena agama tersebut sudah ada dalam jiwa anak tersebut. 6

Pendidikan bukan hanya berkaitan dengan kebutuhan kognitif seseorang, melainkan juga menjadi kebutuhan afektif dan psikomotorik. Keseluruhannya menjadi penting untuk dikembangkan dalam diri seorang anak. Walaupun tidak sepenuhnya sama, konsep pendidikan barat dan Islam memiliki kencenderungan yang sama. Yaitu sama-sama hendak melakukan upaya pendidikan terhadap aspek dhahir dan batin. Hanya sanya menggunakan terminologi yang berbeda. Jika dalam konsep barat pendidikan harus bermuara pada pengembangan kognitif, afektif dan psikomotorik, maka dalam konsep Islam pendidikan harus bermuara pada dimensi 'aqli, (Kognitif) mahsusat (Psikomotorik) dan fitrah (hati/afektif).

\section{Tujuan Pendidikan Anak Usia Dini dalam Al-Qur'an dan \\ Hadits}

Ayat berikut ini adalah berisi tentang cita-cita, tujuan Allah yang termaktub dalam Al Quran :

$$
\text { وَمَا خَلَقُتُ الجِنََّ وَالْإِنْسَ إِلَّا لِيَعْبُدُونِ [الذاريات: 56] }
$$

Dan aku tidak menciptakan jin dan manusia melainkan supaya mereka mengabdi kepada-Ku. [QS. Al Dzariyat : 56]

Sebagaimana telah maklum dalam ilmu nahwu bahwa pengecualian yang terjadi setelah L nafi bermakna "hanya", sehingga makna umum dari ayat ini bahwa Allah menciptakan jin dan manusia hanya untuk menyembah, taat kepada Allah. Hal ini juga selaras dengan pendapat Ibnu Asyur bahwa Allah menciptakan jin dan manusia dengan tujuan ibadah kepadanya, di mana seakan-akan maknanya adalah aku tidak ridho dengan keberadaan jin dan manusia kalau ia tidak kenal dengan Allah. ${ }^{7}$

Berdasarkan ayat di atas, dalam penciptaan manusia terdapat dua dimensi kemanusiaan dari sisi fungsi dan tujuan. Pertama untuk tujuan

${ }^{6}$ Ibnu Al Atsir, Jami'ul Wushul Fi ahadits al Rasul, Jilid I (Maktabah syamilah), hlm. 268 121

7 Ibnu Asyur, Al Tahrir wa Al tanwir, Juz 14 (Maktabah Syamilah), hlm. 
manusia ciptakan sebagai khalifah dan yang kedua sebagai hamba. Khalifah bertugas menjaga dan melestarikan kehidupan di muka bumi, sementara hamba untuk beribadah. Ayat ini sepintas nampak bertentangan dengan ayat berikutnya, namun hakekatnya dapat dikompromikan bahwa seorang khalifah juga harus memiliki dimensi hamba, karena untuk menjadikan dirinya berada dalam ketaatan dan kepatuhan kepada Allah dalam menegakkan kebenaran. Sebagai konsekwensi dari adanya dimensi untuk menjaga dan melestarikan bumi, maka dibutuhkanlah generasi yang miliki pengetahuan, mental kuat dan tekad serta semangat yang tinggi. Pengetahuan yang banyak harus disertai dengan takwaan dan ketaatan.

Dalam Al-Qur'an Allah Swt telah mencontohkan bahwa dibalik penciptaan manusia terdapat tujuan-tujuan yang hendak dicapai. Termasuk dalam urusan bagaimana seseorang mendidik anaknya di masa dini. Sebagaimana ayat berikut ini :

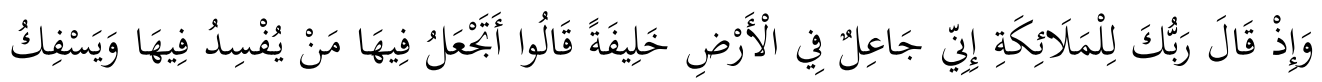

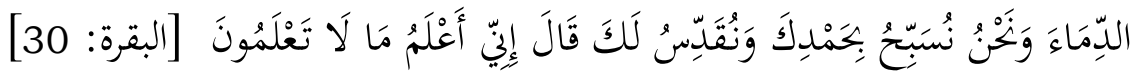

Ingatlah ketika Tuhanmu berfirman kepada para Malaikat: "Sesungguhnya Aku hendak menjadikan seorang khalifah di muka bumi." Mereka berkata: "Mengapa Engkau hendak menjadikan (khalifah) di bumi itu orang yang akan membuat kerusakan padanya dan menumpahkan darah, padahal kami senantiasa bertasbih dengan memuji Engkau dan mensucikan Engkau?" Tuhan berfirman: "Sesungguhnya Aku mengetahui apa yang tidak kamu ketahui." [QS. Al Baqoroh. 30]

Mengenai makna ayat ini, dikatakan oleh al Mawardi bahwa kata khalifah bermakna orang yang mengganti. Dalam konteks ayat ini, Allah Swt dengan sifat kemahakuasaannya hendak menjadikan sesuatu atau hendak menciptakan sesuatu untuk menggantikan sesuatu. Dengan demikian, pada dasarnya terdapat mahluk lain yang ada dimuka bumi ini sebelum adam. Menurut Al Mawardi, yang dikutip dari pendapatnya Ibnu Abbas ra bahwa mahluk tersebut adalah jin. Hanya sanya tatkala jin tersebut menempati bumi, ia selalu melakukan kerusakan dan melakukan permusuhan sehingga menyebabkan pertumpahan darah. Bersamaan dengan itu, kemudian Allah menempatkan Adam dan keluarganya untuk mengganti jin menempati bumi. ${ }^{8}$

Sementara, menurut Hasan Al Bashri, Allah menjadikan Adam sebagai Khalifah atau pengganti jin di muka bumi ini, untuk

8 Al Mawardi, Al Nuktu wa al Uyun, jilid I, (Maktabah Syamilah), hlm. 31 
menegakkan kebenaran dan merawat, memakmurkan bumi. Pendapat ini mengesankan dengan jelas bahwa penciptaan Adam dan penempatannya di bumi dengan tujuan yang jelas. Mengingat, menegakkan kebenaran dan mengurus bumi membutuhkan cara-cara yang baik. Sehingga unsur tujuan yang baik dengan cara yang tepat telah tertuang dalam maksud penciptaan Adam ini. ${ }^{9}$

Ayat lain yang berkaitan dengan ini tujuan pendidikan ini adalah sebagai berikut:

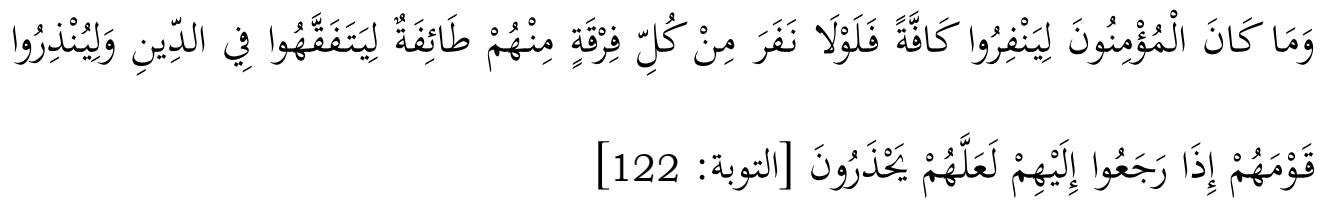

Tidak sepatutnya bagi mukminin itu pergi semuanya (ke medan perang). Mengapa tidak pergi dari tiap-tiap golongan di antara mereka beberapa orang untuk memperdalam pengetahuan mereka tentang agama dan untuk memberi peringatan kepada kaumnya apabila mereka telah kembali kepadanya, supaya mereka itu dapat menjaga dirinya. [QS: Al Taubah. 122]

Ayat ini sebenarnya berkaitan dengan seruan jihad yang sebelumnya di perintahkah oleh Allah. Kemudian orang munafik menegur orang yang tidak ikut perang yang sedang belajar agama. Sehingga turunlah ayat ini guna membenarkan apa yang dilakukan oleh orang mukmin saat itu. Sehingga tidak semua orang mukmin yang tersisa saat itu tetap melakukan aktivitas belajarnya guna mencari ilmu. Supaya ketika mereka dapat memberikan informasi terhadap mereka yang berperang. Dengan demikian, dalam ayat ini terkandung unsur nasyrul 'ilmi, dakwah, sehingga makna kontekstualnya adalah pendidikan untuk anak usia dini dilakukan untuk menanamkan jiwajiwa dakwah, melalui teladan.

\section{Metode Pendidikan Anak Usia Dini dalam Al-Qur'an dan}

\section{Hadits}

\section{a) Metode Teladan}

Dalam teori belajar telah maklum dan sering dijelaskan bahwa anak usia dini memiliki kecenderungan untuk meniru apa yang ada di sekitarnya. Berkaitan dengan apa yang ia lihat, ia dengar dan ia rekam dari lingkungannya. Dengan demikian, alangkah baiknya mana kala yang dijadikan contoh dan teladan adalah hal-hal yang terkait dengan

9 Al Mawardi, Al Nuktu wa al Uyun, jilid I, (Maktabah Syamilah), hlm. 31 
pribadi, sosok, sifat, perilaku dari baginda Nabi Muhammad SAW. Mengingat Allah sendiri telah menjelaskan tentang sosok nabi yang pantas untuk dijadikan sebagai suri teladan.

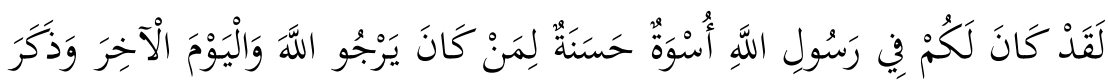

$$
\begin{aligned}
& \text { اللَّه كَثِيرًا (21)؛ }
\end{aligned}
$$

Sesungguhnya telah ada pada (diri) Rasulullah itu suri teladan yang baik bagimu (yaitu) bagi orang yang mengharap (rahmat) Allah dan (kedatangan) hari kiamat dan dia banyak menyebut Allah. [QS: Al Ahzab. 21]

Mengenai makna ayat ini yang berkaitan dengan apa yang harus kita contoh dari nabi, Al Zaidi mengatakan bahwa, kita dapat mencontoh nabi dalam hal kesabaran, syukur nikmat dan keteguhan dalam memegang prinsip agama. ${ }^{10}$ Jika pribadi ini ditanamkan pada diri orang tua dan ditampilkan dalam pola mendidik anak, sebagai niatan untuk menanamkan kebiasaan. Biasa melihat, biasa mendengar dan biasa merasakan.

\section{b) Nasihat}

Metode nasehat yang yang harus dilakukan dalam pendidikan anak usia dini sudah pernah dikisahkan dalam al Quran, terutama berkaitan dengan kisah Lukman dan anaknya. Metode nasihat bisa dalam bentuk, kisah, dongeng, anjuran dan wasiat. Ayat berikut ini merupakan salah satu dari contoh kisah yang berupa nasihat.

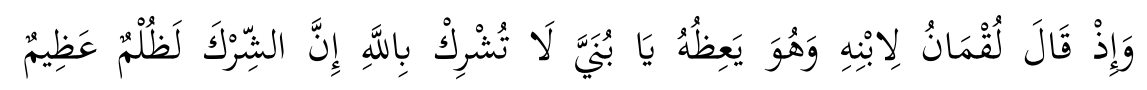

[لقمان: 13]

Dan (ingatlah) ketika Luqman berkata kepada anaknya, di waktu ia memberi pelajaran kepadanya: " Hai anakku, janganlah kamu mempersekutukan Allah, sesungguhnya mempersekutukan (Allah) adalah benar-benar kezaliman yang besar". [QS. Luqman. 13]

Ayat di atas bercerita tentang cara-cara Lukman dalam memberikan nasihat kepada anaknya. Cara ini dilakukannya dengan sangat bijaksana, penuh kesabaran. Wasiat memang cenderung satu arah, namun tidak menutup kemungkinan terjadi dalam bentuk dialog. Berdasarkan ayat ini nampak jelas bahwa Allah Swt mengisahkan sosok Lukman yang memberikan nasihat terhadap anaknya dapat dicontoh

10 Al Zaidi, Tafsir Al 'Aqam, (Maktabah syamilah), hlm. 240 
dalam melakukan pendidikan terhadap anak kita dalam mendidik. Berkaitan dengan kontens nasehat yang disampaikan oleh Lukman terhadap anaknya adalah menyangkut tauhid. Hal ini menurut ulama' karena tauhid adalah lebih penting dari yang lain. ${ }^{11}$

c) Materi Pendidikan Anak Usia Dini dalam Al-Quran dan Hadits

a. Vokasional (Fisik)

Kecenderungan anak untuk melakukan eksplorasi fisik, mengetahui fungsi-fungsi anggota tubuh memang dilakukan oleh anak sejak ia masih usia balita. Sehingga orang tua dituntut untuk dapat menemukan cara bermain yang memuat optimalisasi fungsi fisik. Sebagaimana digambarkan oleh Nabi melalui hadits ini:

$$
\begin{aligned}
& \text { السنن الكبرى للبيهقي وفي ذيله الجهوهر النقي :حَقُّ الَْوَلَدِ عَلَى الْوَالِدِ أَنْ يُعَلِّمَهُ }
\end{aligned}
$$

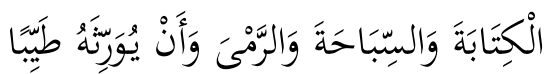

Hak anak dari orang adalah mendapatkan pelajaran tentang menulis, berenang, memanah dan mendapatkan nafkah yang baik. [HR. Al Baihaki] ${ }^{12}$

Melalui hadits ini Nabi hendak menyerukan kepada setiap orang tua, pendidik untuk memaksimalkan potensi motorik anak didik demi kepentingan fungsi-fungsi jasmani anak. Telah diketahui oleh peneliti modern bahwa ternyata memanah dapat menciptakan tingkat konstentrasi bagi anak. Sehingga di samping keterampilan ini berkaitan dengan fisik juga membantu fungsi psikis dan perkembangan akal anak dalam berkonsentrasi.

Anjuran hadits di atas, selaras dengan konsep belajar anak yang harus menerapkan pembelajaran sambil bermain (learning by playing), belajar sambil berbuat (learning by doing) dan belajar melalui stimulus (learning by stimulating). Tiga model pendekatan belajar untuk anak ini masih cukup relevan digunakan untuk kepentingan motorik anak, di mana anak usia dini masih belum memiliki kemampuan yang cukup untuk menalar.

b. Pembiasaan (Akhlak)

Dua hadits di bawah ini menguatkan tentang pentingnya pendidikan budi pekerti, yang ditekankan oleh Allah sejak 
awal. Bahwa pendidikan akhlak merupakan core dari seluruh rangkaian pendidikan. Hal ini selaras dengan semangat kenabian yang dimiliki Nabi Saw yang diutus untuk menyempurkan akhlak manusia.

Dalam konteks pendidikan anak, hadits ini menjadi penjelas yang lebih detil akan kewajiban orang tua terhadap anaknya untuk selalu memberikan pendidikan ahlak yang baik sejak ia masih kecil:

$$
\text { سنن الترمذي: أن رسول الله صلى الله عليه و سلم قال ما نحل والد ولدا من نحل }
$$

Tiada ada pemberian orang tua terhadap anak yang lebih utama dari pada mendidik dengan budi pekerti yang luhur. [HR. Al Turmudzi] ${ }^{13}$

Di antara hadits lain yang bersinggungan dengan konten hadits di atas adalah hadits berikut ini:

$$
\begin{aligned}
& \text { سنن ابن ماجه: سمعت أنس بن مالك يحدث عن رسول الله صلى الله عليه و } \\
& \text { سلم :قال أكرموا أولادكم وأحسنوا أدبمم }
\end{aligned}
$$
akhlaknya. [HR. Ibnu Majjah] ${ }^{14}$

Berkaitan dengan makna dari dua hadits di atas, dalam terminologi pendidikan, seharusnya pendidikan anak usia dini dilakukan mulai sejak dari proses konsepsi, pendidikan dalam kandungan, dalam ayunan, hingga membentuk lingkungan yang kondusif untuk mengeksplorasi pengalaman nyata bagi anak. Memberikan kesempatan yang baik bagi anak untuk meniru, mengamati dan berekspremen dengan bakatnya sendiri secara berulang-ulang. Melalui proses inilah kemudian fungsi-fungsi kecerdasan ini tergerak ke arah pengembangan kognisinya. ${ }^{15}$

Dalam pendidikan akhlak anak usia dini ini, kriteria benar dan salah untuk menilai perbuatan yang muncul merujuk pada Al-Qur'an dan sunnah sebagai sumber tertinggi ajaran Islam. Sebagian orang mengira bahwa tanggung jawab terhadap anak adalah tanggung jawab dalam mencukupi nafkah, pakaian, perhiasan dan hal lain yang bersifat materi saja. Padahal tanggung jawab yang paling besar adalah tanggung

${ }^{13}$ Al Turmudzi, Al Jami' al Shahih, Jilid IV (Maktabah Syamilah), hlm.

14 Ibnu Majjah, Sunan Ibnu Majjah, (Maktabah Syamilah), hlm. 1211

15 Yuliani Nurani Sujiono, Konsep Dasar Pendidikan Anak Usia Dini, (Jakarta: Indesk, 2013), hlm. 7 
jawab pendidikan akhlak mulia serta penanaman nilai dan keteladanan. Semuanya itu terdapat dalam agama yang hanif yaitu Islam. Persoalan pendidikan anak ini dirasa cukup relevan untuk selalu dibincangkan setiap saat. Pendidikan bagi Anak Usia Dini amatlah penting sebagai bekal di masa yang akan datang. Anak Usia Dini meliputi usia 0 sampai 6 tahun. Setiap anak mempunyai karakteristik atau pola perkembangan yang berbeda-beda sesuai dengan tahap perkembangannya. Sedangkan Anak Usia Dini banyak melalui beberapa hal diantaranya yaitu perkembangan fisik dan kognitif. 16

Pada dasarnya anak lahir dalam keadaan lemah tak berdaya dan tidak mengetahui (tidak memiliki pengetahuan) apapun. Akan tetapi Allah membekali anak yang baru lahir tersebut dengan pendengaran, penglihatan dan hati nurani (yakni akal yang menurut pendapat yang sahih pusatnya berada di hati). Menurut pendapat yang lain adalah otak. Dengan itu manusia dapat membedakan di antara segala sesuatu, mana yang bermanfaat dan mana yang berbahaya.

Kemampuan dan indera ini diperoleh seseorang secara bertahap, yakni sedikit demi sedikit. Semakin besar seseorang maka bertambah pula kemampuan pendengaran, penglihatan, dan akalnya hingga sampailah ia pada usia matang dan dewasanya. Dengan bekal pendengaran, penglihatan dan hati nurani (akal), anak pada perkembangan selanjutnya akan memperoleh pengaruh sekaligus berbagai didikan dari lingkungan sekitarnya.

16 Abdul Majid dan Dian Andayani, Pendidikan Karakter Perspektif Islam, (Bandung: Pustaka Media, 2016), 78 


\section{Skema Grand Design Pendidikan Anak Usia Dini}

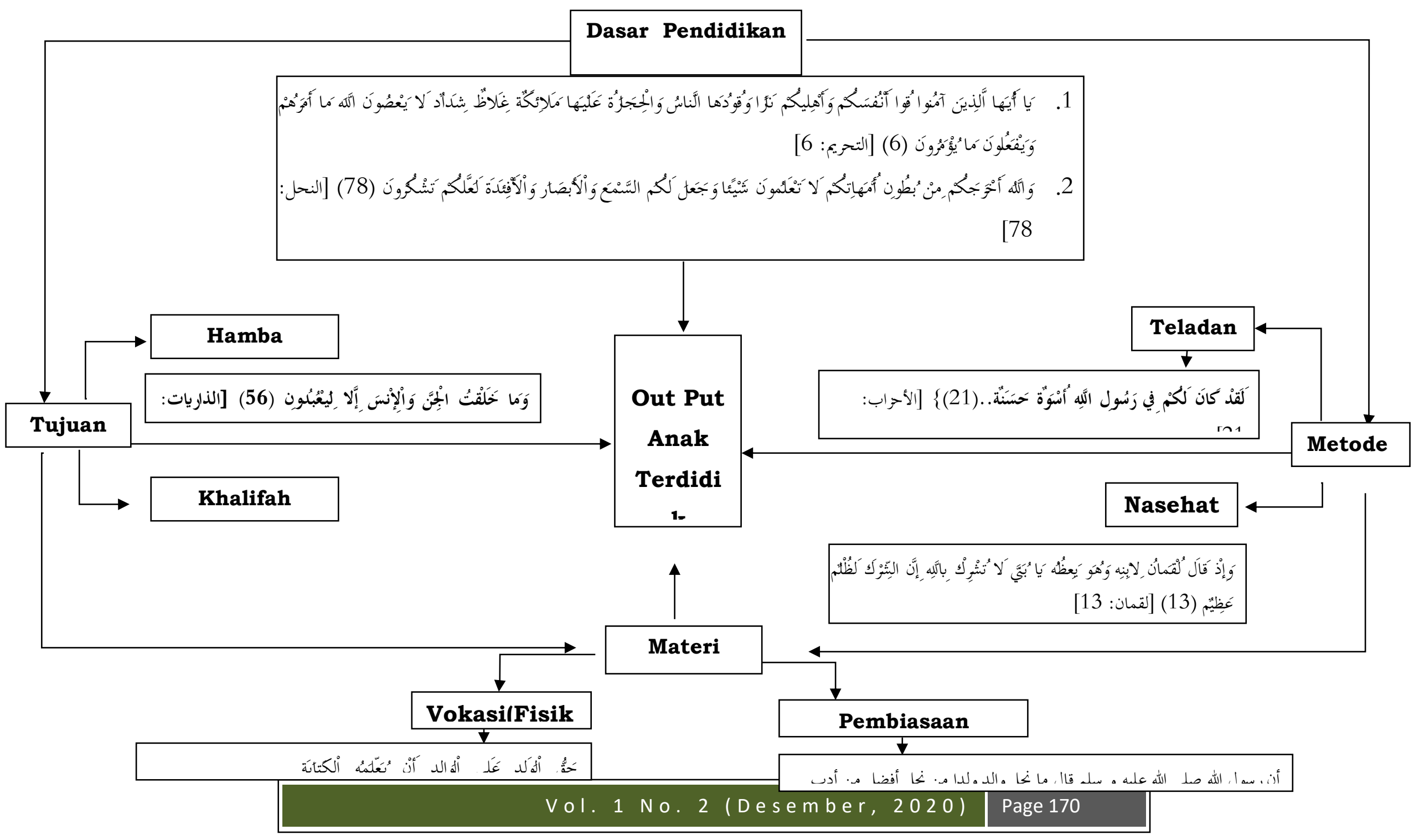




\section{Penutup}

Berdasarkan uraian di atas dapat disimpukan beberapa poin terkait dengan desain pendidikan anak usia dini adalah sebagai berikut :

Pada dasarnya pendidikan anak usia dini sudah dijelaskan dalam al-Qur'an terkait dengan urgensinya. Mengingat anak sangat rentan dipengaruhi oleh lingkungan yang membesarkannya. Adapun tujuan pendidikan sebagaimana dimaksudkan dalam al-Qur'an dan Hadits adalah untuk menjadi diri anak manusia menjadi sosok hamba dan khalifah atau dalam istilah pemikiran pendidikan adalah ulama' dan intelektual. Metode yang dapat digunakan dalam pendidikan anak adalah metode teladan yang menyebabkan anak dapat meniru apa yang ia lihat. Yang kedua adalah nasihat yang dapat menyebabkan anak dapat mengerti dan paham apa yang disampaikan oleh pendidik dan menjadi kebiasaan dalam perilakunya. Adapun materi yang dapat disampaikan adalah berkaitan dengan pendidikan vokasional dan akhlak, seperti berenang, memanah dan bentuk penanaman moral lainnya.

\section{Daftar Rujukan}

Abu Hamid Muhammad bin Muhammad, Ihya' Ulumiddin, Jilid III, (Beirut: Darul Fikr, tt).

Al-Atsir, Ibnu. Jami'ul Wushul Fi ahadits al Rasul, Jilid I (Maktabah syamilah).

Al-Baihaki, Sunan Al Qubra, jilid X (Maktabah Syamilah).

Al-Baihaki, Sunan al Qubra, Jilid VI, (maktabah syamilah).

Al-Mawardi, Al Nuktu wa al 'Uyun, Jilid IV (Maktabah syamilah).

Al-Mawardi, Al Nuktu wa al Uyun, jilid I, (Maktabah Syamilah).

Ar Razi, Fakhruddin .Mafati al Gaib, (Maktabah Syamilah).

As-Syaukani, Fath Al Qadir, Jilid V (Maktabah Syamilah).

Asyur, Ibnu. Al Tahrir wa Al tanwir, Juz 14 (Maktabah Syamilah).

At-Turmudzi, Al Jami' al Shahih, Jilid IV (Maktabah Syamilah).

Az Zaidi, Tafsir Al 'aqom, (Maktabah Syamilah).

Majjah, Ibnu. Sunan Ibnu Majjah, (Maktabah Syamilah). 
Judul: Desain Pendidikan Anak Usia Dini Dalam Perspektif Al-Qur'an dan Hadits Penulis: Sulaiman

Sujiono, Yuliani Nurani. Konsep Dasar Pendidikan Anak Usia Dini, (Jakarta: Indesk, 2013). 